\title{
Effect of Sacha Inchi Oil (Plukenetia volubilis L.) on Genotoxicity in Mice (Mus musculus) and Subchronic Toxicity in Goldfish (Carassius auratus)
}

\author{
Oscar Herrera-Calderon ${ }^{1, *}$, Jorge Luis Arroyo-Acevedo ${ }^{2}$, Roberto Chávez-Asmat ${ }^{3}$, Juan Pedro Rojas-Armas ${ }^{2}$, \\ Edwin Enciso-Roca ${ }^{4}$, Victor Chumpitaz Cerrate ${ }^{5}$, Cesar Franco-Quino ${ }^{6}$, Luz Chacaltana-Ramos ${ }^{7}$, Ricardo Ángel \\ Yuli-Posadas $^{8}$
}

Oscar Herrera-Calderon ${ }^{1, *}$, Jorge Luis Arroyo-Acevedo², Roberto Chávez-Asmat ${ }^{3}$, Juan Pedro Rojas-Armas ${ }^{2}$, Edwin Enciso-Roca ${ }^{4}$, Victor Chumpitaz Cerrate $^{5}$, Cesar Franco-Quino ${ }^{6}$, Luz Chacaltana-Ramos ${ }^{7}$, Ricardo Ángel Yuli-Posadas ${ }^{8}$

${ }^{1}$ Faculty of Pharmacy and Biochemistry, Universidad Nacional Mayor de San Marcos, Lima 15001, PERU.

${ }^{2}$ Faculty of Medicine, Universidad Nacional Mayor de San Marcos, Lima 15001, PERU. ${ }^{3}$ Association for the Development of Student Research in Health Sciences (ADIECS), Faculty of Medicine, Universidad Nacional Mayor de San Marcos, Lima 15001, PERU.

${ }^{4}$ Faculty of Health Sciences, Universidad Nacional de San Cristóbal de Huamanga, Ayacucho 05001, PERU.

${ }^{5}$ Laboratory of Pharmacology, Universidad Cientifica del Sur, Lima 15001, PERU

${ }^{6} \mathrm{~S}$ chool of Public Health and

Administration, Universidad Peruana

Cayetano Heredia, Lima 15001, Peru.

${ }^{7}$ Faculty of Pharmacy and Biochemistry,

Universidad Nacional San Luis Gonzaga, Ica 11001, PERU

${ }^{8}$ Universidad Continental, Huancayo 12002, PERU.

\section{Correspondence}

\section{Oscar Herrera Calderon}

Faculty of Pharmacy and Biochemistry, Universidad Nacional Mayor de San

Marcos, Jr Puno 1002, Lima, PERU.

Phone no: Tel.: +51-956-550-510

E-mail: oherreraca@unmsm.edu.pe

History

- Submission Date: 11-08-2019;

- Review completed: 09-09-2019;

- Accepted Date: 09-09-2019.

DOI : 10.5530/pj.2019.11.237

Article Available online http://www.phcogj.com/v11/i6s

\section{Copyright}

(C) 2019 Phcogi.Com. This is an openaccess article distributed under the terms of the Creative Commons Attribution 4.0 International license.

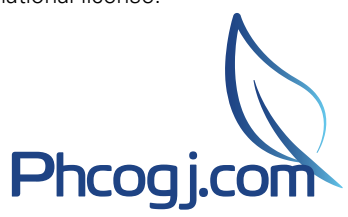

\begin{abstract}
Introduction: Plukenetia volubilis is known as Sacha Inchi (SI) is originary from the peruvian amazone and it has been cultivated and consumed since the pre and Inca's time. Objective: Sacha inchi oil was assessed for genotoxicity in Balb $\mathrm{C}$ albino mice and subchronic toxicity in goldfish (Carassius auratus). Material and Methods: The genotoxicity was assessed in Mus musculus Balb $C(n=25)$ separated into five groups randomly selected of twenty-five each one. Groups were $10 \mathrm{~mL} / \mathrm{kg}$ normal saline (NS), $40 \mathrm{mg} / \mathrm{kg}$ cyclophosphamide group (CP) and the three other groups received cyclophosphamide and sacha inchi oil of concentrations 10,100 and $1000 \mathrm{mg} / \mathrm{kg}$ respectively. The substances were administered three times during 24 hours. The genotoxicity in mice was evaluated determining micronucleus levels in blood and bone marrow. The subchronic toxicity was assessed in goldfish (Carassius auratus) ( $\mathrm{n}=$ 48) separated into four groups randomly selected of six each: normal saline group (control) and three groups that received doses of 10,100 and $1000 \mu \mathrm{g}$ sacha inchi oil per litre of water respectively for 45 days. Results: The values of weight, length, growth rate, condition factor (K) and number of survivors were recorded. CP group showed higher micronuclei levels in blood and bone marrow compared with sacha inchi oil 10, 100 and $1000 \mathrm{mg} / \mathrm{kg}$ groups (ANOVA Test $p<0.01$ Scheffe's Post Hoc $p<0.05, p<0.01$ and $p<0.001$ respectively). The subchronic toxicity assessment in goldfish showed isometric growth, a decline in " $K$ " and a similar specific percentage growth rate per day in all groups (ANOVA test $p>0.05$ ). Conclusion: Sacha inchi oil was not toxic under experimental conditions.
\end{abstract}

Key words: Sacha Inchi Oil, Plukenetia Volubilis, Genotoxicity, Subchronic Toxicity.

\section{INTRODUCTION}

Medicinal plants have important uses in the traditional medicine in worldwide due to its content of phytochemicals and source of drug discovery. Their medicinal value is based on their pharmacological action on the human and animal organism. ${ }^{1}$ However, these substances can also have toxic effects. It is known that $80 \%$ of the world population relies on using plants to alleviate the pain of some illnesses. Therefore, the WHO (World Health Organization) insists that the use of medicinal plants can be of great use to primary health care systems, but based on scientific evidence that shows the safety, effectiveness and quality required for human consumption., ${ }^{2,3}$

Sacha inchi (Plukenetia volubilis L.; Family: Euphorbiaceae) is distributed from Central America to Bolivia. In Peru, it is found mainly in the high and low forest, at heights ranging from 100 to 2000 meters in height, areas with average annual rainfall of $1084 \mathrm{~mm}^{3}$ and temperatures ranging between 30 and $36.6{ }^{\circ} \mathrm{C} .{ }^{4}$ Studies carried out in this plant reveals high content of omega 3 and 6 with respect to soybean, corn, peanut, sunflower, cotton, palm and olive seeds. ${ }^{5}$ Sacha inchi oil is extracted from seeds using cold pressing (commercial oil press), Soxhlet extraction, and supercritical $\mathrm{CO}_{2}$ methods. Furthermore, it is known that present considerable amounts of polyunsaturated fatty acids (PUFA), which are essential for the human organism. ${ }^{6}$ Otherwise, it has been described numerous effects as cardioprotective, antiarrhythmic, antiinflammatory, hypotensive, neuroprotective, hypotriglyceridemic and hypocholesterolemic. ${ }^{7}$

The Guidelines of the Scientific Committee on Food for safety assessment of substances used in food contact materials recommend genotoxicity and subchronic studies in the core set of tests. In Peru and other countries, sacha inchi oil is commercialized and consumed based on its potential beneficial effects, there are no evidences reported of genotoxicity assays of sacha inchi oil. It is outstanding one whose results show that oral administration for 60 days in rats is safety, and the lethal dose $50\left(\mathrm{LD}_{50}\right)$ above $37 \mathrm{~g} / \mathrm{kg}$ of body weight in mice was determined. ${ }^{8}$ Based on that, the present study aimed to evaluate the genotoxicity and subchronic toxicity of Sacha inchi oil (Plukenetia volubilis $L$.) when it is administered in mice and fish, respectively.

Cite this article: Herrera-Calderon $\mathrm{O}$, Arroyo-Acevedo $\mathrm{JL}$, Chávez-Asmat R, Rojas-Armas JP, Enciso-Roca E, Chumpitaz-Cerrate V, et al. Effect of Sacha Inchi Oil (Plukenetia volubilis L.) on Genotoxicity in Mice (Mus musculus) and Subchronic Toxicity in Goldfish (Carassius auratus). Pharmacog J. 2019;11(6)Suppl:1549-57. 


\section{MATERIAL AND METHODS}

\section{Chemicals}

The materials applied in this research are as follows: Cyclophosphamide monohydrate $\left(\mathrm{C}_{7} \mathrm{H}_{15} \mathrm{C}_{12} \mathrm{~N}_{2} \mathrm{O}_{2} \mathrm{P} \cdot \mathrm{H}_{2} \mathrm{O}\right)$ and fetal bovine serum (FBS) (Sigma-Aldrich, St. Louis, MO, USA); Giemsa stain; EDTA; Triton X-100 (Merck, Lima, Peru); and all chemicals used in our study were of analytical or reagent grade.

\section{Sacha inchi oil analysis}

Sacha inchi oil was elaborated in our laboratory by cold pressing. The determination of the fatty acids was carried out using the method of Ichihara and Fukubayashi (2010), which consisted of adding $0.2 \mathrm{~mL}$ of toluene, $1.5 \mathrm{~mL}$ of methanol and $0.3 \mathrm{~mL}$ of the mixture (HCl: methanol 1: 4.3 ) to $1 \mathrm{mg}$ of sacha inchi oil and $0.1 \mathrm{mg}$ of methyl tricosanoate (internal standard). Next, the mixture is incubated at $45^{\circ} \mathrm{C}$ for 14 hours for the derivation, the methylesters were extracted with $1.5 \mathrm{~mL}$ of $\mathrm{n}$-hexane and $1 \mathrm{~mL}$ of water to be analyzed by gas chromatography in a Varian equipment CP-3800, under the following conditions: The gas chromatograph was equipped with a column Restek, FAMEWAX WCOT fused silica, of $30 \mathrm{~m}$ x $0.25 \mathrm{~mm} \times 0.25 \mu \mathrm{m}$ film thickness. The oven temperature was held at $120^{\circ} \mathrm{C}$ for $1 \mathrm{~min}, 30^{\circ} \mathrm{C} / \mathrm{min}$ until 160 ${ }^{\circ} \mathrm{C}, 160{ }^{\circ} \mathrm{C}$ for $1 \mathrm{~min}, 4{ }^{\circ} \mathrm{C} / \mathrm{min}$ until $240{ }^{\circ} \mathrm{C}, 240{ }^{\circ} \mathrm{C}$ for $7 \mathrm{~min}$, and maintained at $250^{\circ} \mathrm{C}$ for $30.33 \mathrm{~min}$. Helium was used as carrier gas at $22 \mathrm{psi}$ and the injection volume was $1 \mu \mathrm{L} .^{9}$

\section{Genotoxicity oral assessment in normal mice}

Oral genotoxicity of the Sacha inchi oil (SI) was assessed in normal mice. According to OECD $474^{10}$ and Schmid. ${ }^{11}$ Twenty Balb/C albino mice with average weights of $25 \pm 5 \mathrm{~g}$ from the National Institute of Health of Peru (INS) were kept in the bioterium of the Faculty of Medicine (UNMSM). The experiment began with a 48 -hour pre conditioning period. Mice were given food and water ad libitum access, 12 hours' light / dark cycle, temperatures between $22-26^{\circ} \mathrm{C}$ and $60 \pm 10 \%$ of relative humidity.

During the entire experimental process, international ethical principles for research using laboratory animals were respected. ${ }^{12}$ The evaluation separated the research specimens into 5 groups of 5 mice each one: the control group received $10 \mathrm{~mL} / \mathrm{kg}$ of normal saline (NS); cyclophosphamide group (CP) received cyclophosphamide 40 $\mathrm{mg} / \mathrm{kg}$ and the three other groups (SI-10, SI-100, SI-1000) received cyclophosphamide and sacha inchi oil of concentrations at 10,100 and $1000 \mathrm{mg} / \mathrm{kg}$ respectively. Animals were orally exposed to the substances, twice a day during 14 days. At the end of the experiment, mice were place into a glass chamber where they became anesthetized with ether. Peripheral blood was obtained by cardiac puncture to prepare blood film which allows evaluate the micronuclei frequency in blood.

Then, mice were euthanized by intraperitoneal injection of sodium pentobarbital $100 \mathrm{mg} / \mathrm{kg}$. Next, the femoral bone marrow was extracted with $3 \mathrm{ml}$ of fetal bovine serum (FBS) and centrifuged at $1000 \mathrm{rpm}$ for 10 minutes. Once the supernatant was removed, the cell button was dispersed over slides. The slides (minimum 2 per animal) were left to dry at room temperature for 24 hours. They were fixed with methanol for 5 minutes and stained with 5\% Giemsa stain for 12-15 minutes. The slides were coded and examined by two independent observers (blind) under Olympus BH-2 microscope (100x oil immersion lens). The number of micronuclei per field was recorded

\section{Subchronic toxicity assessment in gold fish}

The subchronic toxicity assessment of SI in normal goldfish was carry out according to OECD $305^{12}$ and Gutierrez et al..$^{13}$ Forty-eight goldfishes (Carassius auratus) of 15-days of age were kept into tanks of
$20 \mathrm{~L}$ of capacity, which contained $1 \mathrm{~L}$ of dechlorinated water per gram of body weight for each fish. Fishes were acclimatized to experimental conditions 15 days prior to the start of the experiment. They were exposed to a 12-hour light/dark cycle. The fish were fed with a standard diet, which it contained marine algae in amounts ranging from 1 to $2 \%$ of body weight for each fish. Water parameters were measured and controlled such as: temperature: $22-26^{\circ} \mathrm{C}$; $\mathrm{pH}$ : $6.0-8.5$; and more than $60 \%$ of available oxygen. The study was carried out using four experimental groups randomly selected of six goldfish each one: normal saline group (NS) and three groups (SI-10, SI-100, SI-1000) that received doses of 10,100 and $1000 \mu \mathrm{g}$ of sacha inchi oil per litre of water respectively.

There were two series for each experimental group. The solution of sacha inchi oil was prepared using $50 \mathrm{mg}$ of polysorbate 80 per litre of dechlorinated water. It was added to the tanks every 48 hours for 45 days ( 7 weeks), immediately after the water change. The fish were weighted and measured longitudinally from head to tail weekly. Behavioural signs as motility, colour, motion complexity, appearance of fungi respect to the control group were observed daily. The number of surviving fish was recorded weekly.

\section{Statistical analysis}

\section{Genotoxicity in mice}

Numerical variables were described with measures of central tendency and dispersion, mean and standard deviation, respectively. The normality and homogeneity of variance were evaluated using the Shapiro-Wilkt's and Barlett's tests, respectively. Subsequently, an analysis of variance (ANOVA) with post hoc Tukey's test was used with variables that showed significant difference $(p<0.05)$ between the groups. All statistical analysis was performed using SPSS V 21.0 software.

\section{Subchronic toxicity to fish}

The length-weight relationships were established using linear regression. The LWR was estimated by using the equation $\mathrm{W}=\mathrm{al}^{\mathrm{b}}(\mathrm{W}=$ total weight expressed in grams, $\mathrm{L}=$ length expressed in centimeters). ${ }^{13,14}$ Since the length is a linear scale and the weight is equal to the cube of it; if the shape of the fish is consistent throughout development, the growth is isometric $(b=3)$. When $b>3$, the fish grows faster in weight than in length. The fish growth is positive allometric. In contrast; when b $<3$, the fish grows faster in length than in weight. The fish growth is negative allometric. In the study, if $\mathrm{b}$ ranged between 2.5 and 3.5, the fish growth was considered isometric..$^{15}$

The condition per individual was estimated using the Fulton index $(\mathrm{K})$, $\mathrm{K}=\left(\mathrm{W} / \mathrm{L}^{3}\right) \times 100$, where $W$ is the whole body wet weight expressed in grams and $L$ is the length expressed in centimeters. The annual variation of $\mathrm{K}$ was estimated using a one-way ANOVA and analyzing the data. In order to estimate the growth rate in weight and length, the equation of specific percentage growth rate per day regarding the length and weight $[$ SGR $(\% \mathrm{X}$ day $)]=[(\ln$ final X)-ln $($ initial X) $) /$ treatment time $] \times 1000$ was used. According to Gill, $\mathrm{X}$ can be weight or length. ${ }^{16}$

\section{RESULTS}

In the analysis by gas chromatography was determined: Palmitic acid (C16: 0) $10.67 \pm 0.06 \%$, Stearic acid (C18: 0): $4.36 \pm 0.01 \%$, Oleic acid (C18: 1): $21.10 \pm 0.02 \%$, Linoleic acid (C18: 2):50.36 $\pm 0.01 \%$, a-linolenic acid (C18: 3): $12.20 \pm 0.02 \%$ and Vaccenic acid (C18: 7): $1.31 \pm 0.004 \%$ (Figure 1 and Table 1 ).

The genotoxicity in mice was evaluated by determining micronucleus levels in blood. The CP group showed $13.20 \pm 0.22$ micronuclei. The level of micronucleus was higher in CP group compared with the groups that received 10, 100 and $1000 \mathrm{mg} / \mathrm{kg}$ of sacha inchi oil (ANOVA Test 

auratus)

$p<0.01$ Scheffe's Post Hoc $p<0.05, p<0.01$ and $p<0.001$ respectively). The inhibition of micronuclei was higher than $50 \%$ for both the group of 100 and $1000 \mathrm{mg} / \mathrm{kg}$ of sacha inchi oil (Table 2).

The evaluation of genotoxicity in mice by determining micronucleus levels in bone marrow showed $1.80 \pm 0.14$ in the $\mathrm{CP}$ group. The level of micronucleus was higher in CP group compared with the groups that received 10, 100 and $1000 \mathrm{mg} / \mathrm{kg}$ of sacha inchi oil (ANOVA Test $p$ $<0.01$ Scheffe's Post Hoc $p<0.05, p<0.01$ and $p<0.001$ respectively). The inhibition of micronuclei was higher than $60 \%$ for both the 10 and $100 \mathrm{mg} / \mathrm{kg}$ of sacha inchi oil (Table 3).

Body weight and head-tail length were monitored for 7 weeks. All the fish were observed thoroughly for the onset of any signs of subchronic toxicity. All the groups showed homogeneous growth rate (ANOVA test $p>0.05)$. However, the body weight of the SI-10 group at the end of the study was greater than the NS group (Student's T test $p>0.05$ ) and the head-tail length of the SI-1000 group at the end of the study was greater than the NS group (Student's T test $p>0.05$ ) (Figure 2). There was a decrease in the condition factor ranging from $17.76 \pm 0.97$ (Week
0) to $10.48 \pm 0.87$ (Week 7) in all treatment groups (Figure 3). The specific percentage growth rate per day regarding the length and weight was similar in all treatment groups (ANOVA Test $p>0.05$ ) (Figure 4). Isometric growth was found with values obtained from $b$ ranging from 2.6 and 3.4.

\section{DISCUSSION}

Genetic toxicity or genotoxicity is the process made by an agent that induces damage to DNA and other cellular targets that control the integrity of genetic material. ${ }^{17}$ The assessment of genotoxicity using micronuclei in blood and bone marrow of mammals is used to detect lesions in chromosomes or mitotic apparatus of erythroblasts. Erythrocytes taken from the bone marrow and / or peripheral blood of animals (usually rodents) are analyzed to determine chromosomal lesions in a living system. Genotoxic substances cause cytogenetic damage leading to the formation of micronuclei containing chromosomal fragments and whole lagging chromosomes ${ }^{24}$. When the erythroblasts of the bone marrow became polychromatic erythrocyte, the main nucleus is expelled and the micronucleus remains in the

Table 1: Percentage of fatty acids determined in Sacha inchi oil.

\begin{tabular}{ccc}
\hline Fatty acids & $(\mathrm{x} \pm \mathrm{SD}) \mathrm{mg} / \mathrm{g}$ & $\%$ \\
\hline Palmitic acid (16:0) & $104.76 \pm 2.66$ & 10.67 \\
Stearic acid (18:0) & $42.83 \pm 1.23$ & 4.36 \\
Oleic acid (18:1n-7) & $12.85 \pm 0.34$ & 1.31 \\
Linoleic acid (18:1n-9) & $207.28 \pm 5.45$ & 21.10 \\
a-linolenic acid (18:2n-6) & $494.61 \pm 13.02$ & 50.36 \\
Vaccenic acid (18:3n-3) & $119.87 \pm 3.09$ & 12.20 \\
$\approx 3 / \approx 6$ & 0.24 & - \\
\hline
\end{tabular}

Table 2: Number of micronuclei obtained to evaluate the genotoxicity of sacha inchi oil in erythrocytes of peripheral blood of Mus musculus (OECD 474).

\begin{tabular}{|c|c|c|c|c|c|c|c|}
\hline \multirow{2}{*}{ Treatment } & \multirow{2}{*}{ Average } & \multirow{2}{*}{ Estandar error } & \multicolumn{2}{|c|}{ 95\% Confidence intervals } & \multicolumn{2}{|c|}{ Value } & \multirow{2}{*}{$\% \mathrm{IM}$} \\
\hline & & & Lower limit & Upper limit & Minimum & Maximum & \\
\hline Normal saline (NS) & 0.20 & 0.09 & 0.01 & 0.39 & 0 & 1 & ---- \\
\hline Cyclophosphamide (CP) $40 \mathrm{mg} / \mathrm{Kg}$. & $13.20^{\mathrm{a}, \mathrm{b}, \mathrm{c}}$ & 0.22 & 12.73 & 13.67 & 12 & 14 & 0.00 \\
\hline $\mathrm{CP}+$ Sacha inchi $10 \mathrm{mg} / \mathrm{Kg}$ & $11.95^{\mathrm{a}}$ & 0.33 & 11.26 & 12.64 & 10 & 13 & 9.47 \\
\hline $\mathrm{CP}+$ Sacha inchi $100 \mathrm{mg} / \mathrm{Kg}$ & $6.30^{\mathrm{b}}$ & 0.16 & 5.96 & 6.64 & 5 & 7 & 52.27 \\
\hline $\mathrm{CP}+$ Sacha inchi $1000 \mathrm{mg} / \mathrm{Kg}$ & $4.80^{c}$ & 0.42 & 3.92 & 5.68 & 2 & 6 & 63.64 \\
\hline
\end{tabular}

$\% \mathrm{IM}=$ Inhibition of Micronuclei $=\left[((\mathrm{CP}-\mathrm{NS}) / \mathrm{CP})^{\star} 100\right]$

CP: Cyclophosphamide, SI: Sacha inchi oil

ANOVA Test $p<0.01$ Scheffe's Post Hoc $\mathrm{a}=p<0.05, \mathrm{~b}=p<0.01 \mathrm{y} \mathrm{c}=p<0.001$

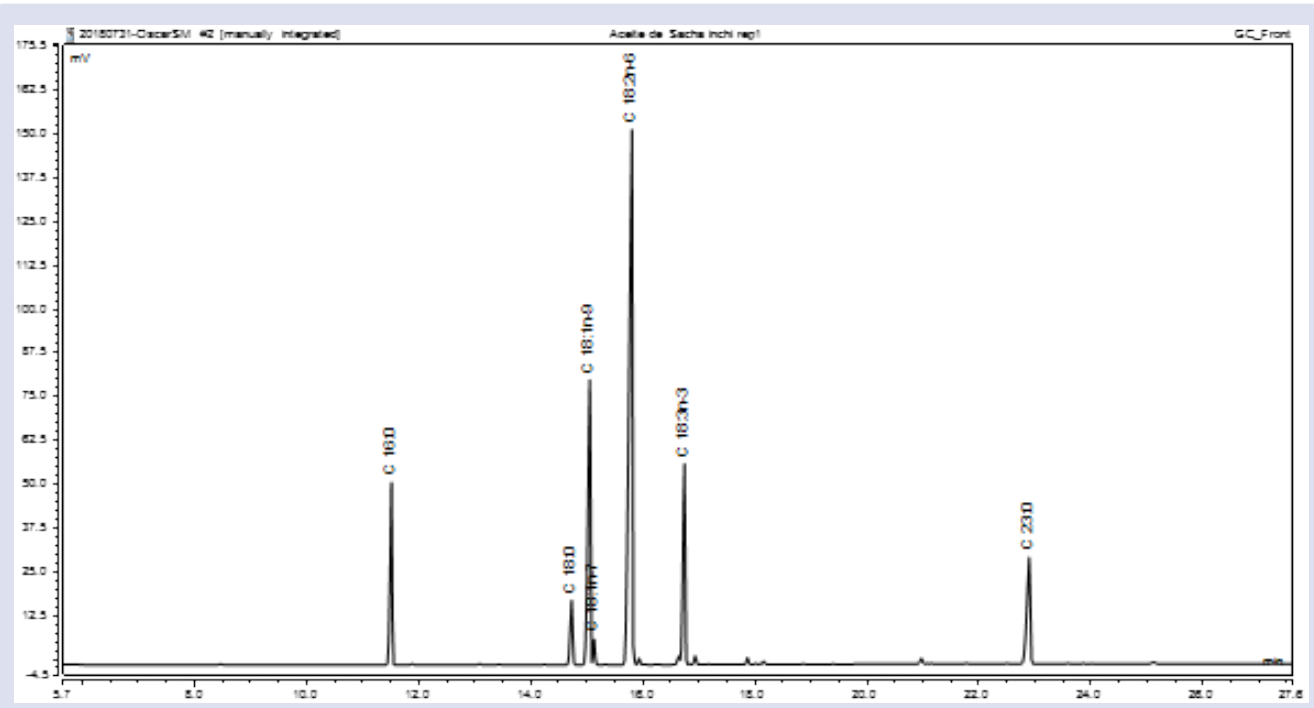

Figure 1: Chromatographic profile of sacha inchi oil by GC-FID. 
Herrera-Calderon, et al.: Effect of Sacha Inchi Oil (Plukenetia volubilis L.) on Genotoxicity in Mice (Mus musculus) and Subchronic Toxicity in Goldfish (Carassius auratus)

Table 3: Number of micronuclei obtained to evaluate the genotoxicity of sacha inchi oil in erythrocytes of bone marrow of Mus musculus (OECD 474).

\begin{tabular}{|c|c|c|c|c|c|c|c|}
\hline \multirow{2}{*}{ Treatment } & \multirow{2}{*}{ Average } & \multirow{2}{*}{$\begin{array}{c}\text { Estandar } \\
\text { error }\end{array}$} & \multicolumn{2}{|c|}{$95 \%$ Confidence intervals } & \multicolumn{2}{|c|}{ Value } & \multirow{2}{*}{$\%$ IM } \\
\hline & & & Lower limit & Upper limit & Minimum & Maximum & \\
\hline Normal saline & 0.10 & 0.10 & -0.11 & 0.31 & 0 & 2 & ---- \\
\hline Cyclophosphamide (CP) 40 mg/Kg. & $1.80^{\mathrm{a}, \mathrm{b}, \mathrm{c}}$ & 0.14 & 1.51 & 2.09 & 0 & 2 & 0.00 \\
\hline $\mathrm{CP}+$ Sacha inchi $10 \mathrm{mg} / \mathrm{Kg}$ & $0.65^{\mathrm{a}}$ & 0.11 & 0.42 & 0.88 & 0 & 1 & 63.89 \\
\hline $\mathrm{CP}+$ Sacha inchi 100 mg/Kg & $0.60^{\mathrm{b}}$ & 0.11 & 0.36 & 0.84 & 0 & 1 & 66.67 \\
\hline $\mathrm{CP}+$ Sacha inchi $1000 \mathrm{mg} / \mathrm{Kg}$ & $1.00^{c}$ & 0.00 & 1.00 & 1.00 & 1 & 1 & 44.44 \\
\hline
\end{tabular}

\% IM = Inhibition of Micronuclei $=\left[((\mathrm{CP}-\mathrm{NS}) / \mathrm{CP})^{\star} \mathbf{1 0 0}\right]$

CF: Cyclophosphamide, SI: Sacha inchi oil

ANOVA Test $p<0.01$ Scheffe's Post Hoc $\mathrm{a}=p<0.05, \mathrm{~b}=p<0.01 \mathrm{y} \mathrm{c}=p<0.001$
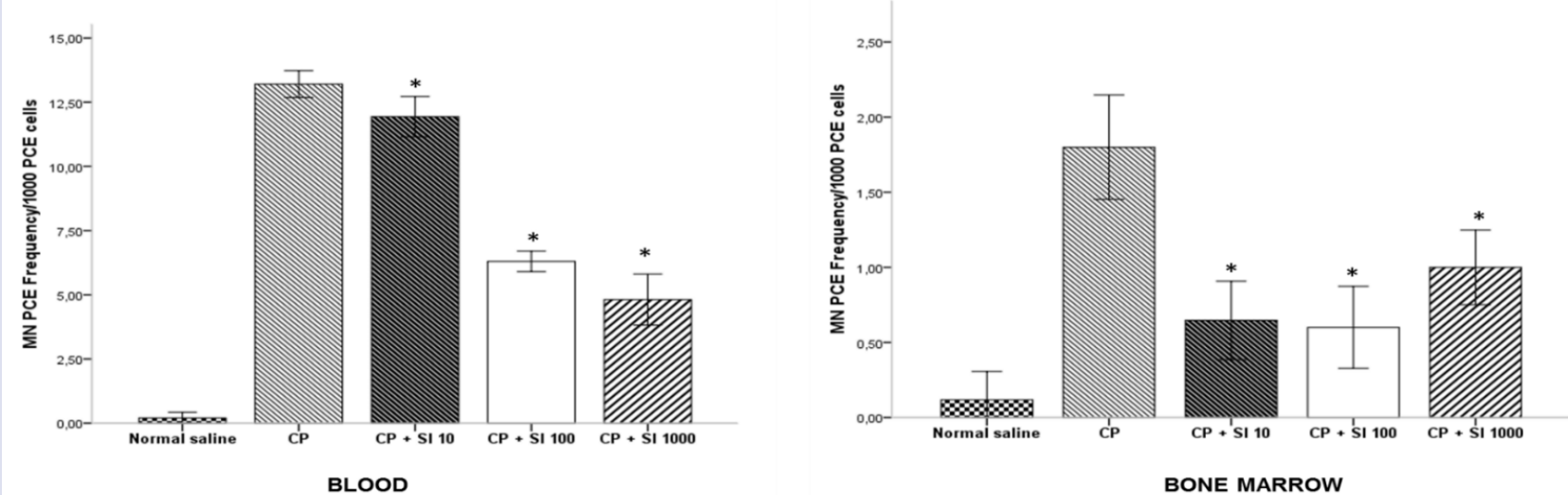

Figure 2: Effect of Sacha inchi oil (Plukenetia volubilis L.) on the frequency of micro nucleated polychromatic erythrocytes (MNPCE).

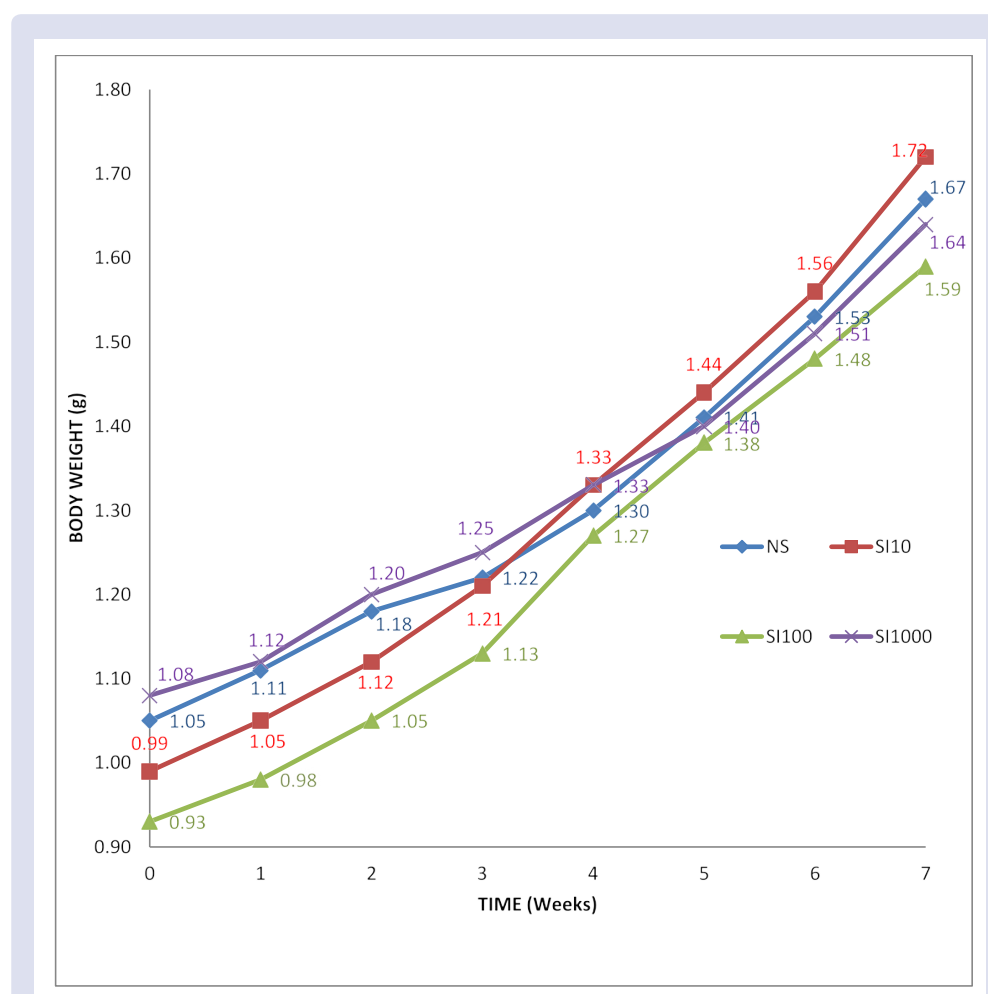

Figure 3: Body weight in goldfish.

NS: Normal saline SI-10: sacha inchi oil $10 \mu \mathrm{g} / \mathrm{L}$, SI-100: sacha inchi oil $100 \mu \mathrm{g} / \mathrm{L}$, $\mathrm{SI}-1000$ : sacha inchi oil $1000 \mu \mathrm{g} / \mathrm{L}$. Each point represents a mean value of six fish. 


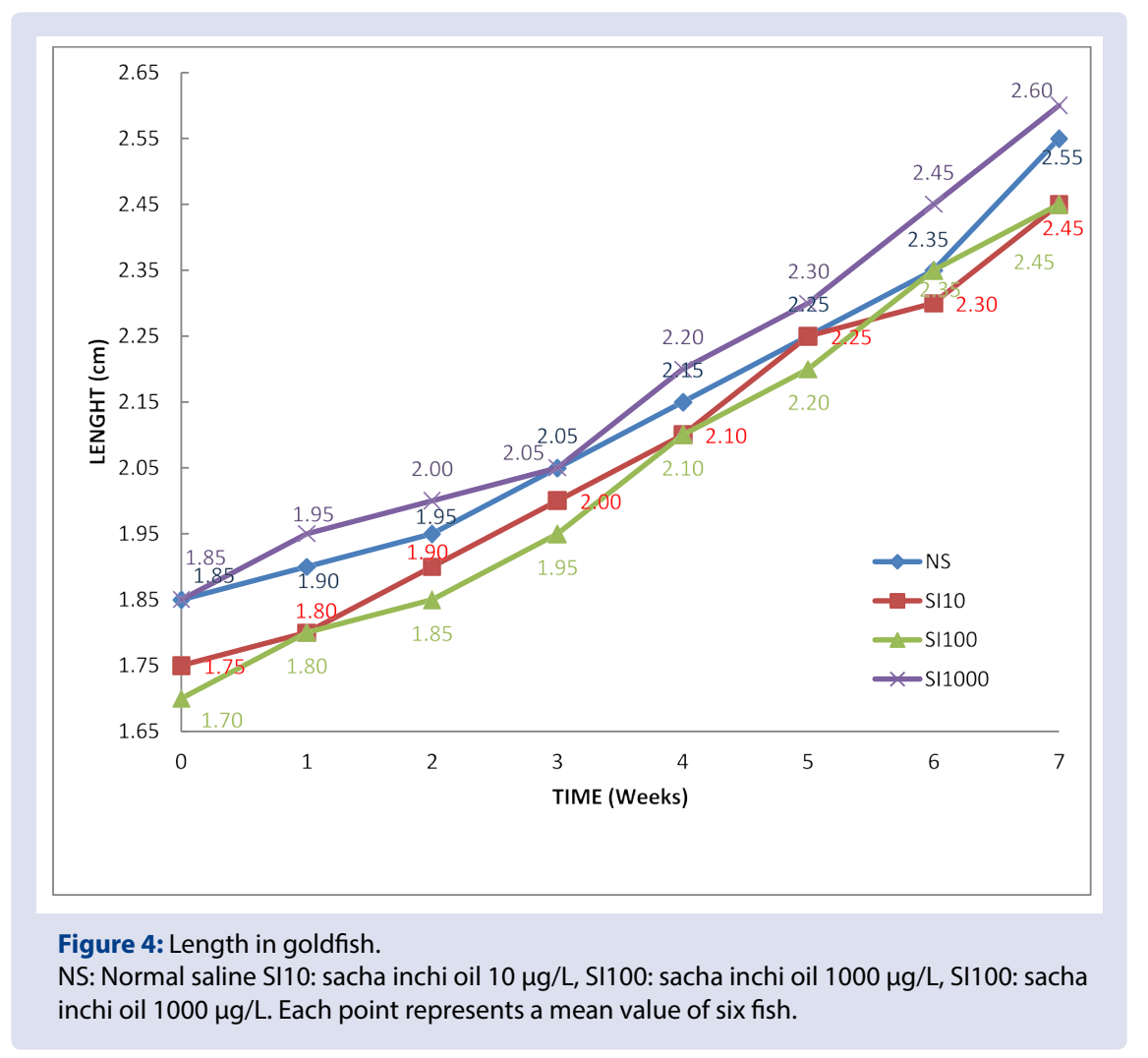

cytoplasm, otherwise the cell would be anucleated. Because of the lack of a main nucleus, is easier to visualize the micronuclei in these cells. An increased micronuclei frequency in polychromatic erythrocytes is indicative of the existence of induced chromosome damage. ${ }^{18}$

Studies with cyclophosphamide demonstrate an intimate relationship between chromosomal damage and teratogenic effects caused by this substance in fetal liver, and during pregnancy in mice. ${ }^{19-21}$ Likewise, Cancino ${ }^{22}$ and $\mathrm{Matuo}^{23}$ demonstrated the efficient use of cyclophosphamide as a positive control in the assays of teratogenicity in rats and mice for their clastogenic and aneugenic effects. Tables 2 and 3 show the sensitivity of cyclophosphamide to evaluate the genotoxicity of sacha inchi oil in erythrocytes of blood and bone marrow. The values were within normal limits, 13.20 and 1.80 micronuclei respectively. Cyclophosphamide is an alkylating agent which reparative mechanisms have ruptures effects formatting monoadducts and cross-links between chains. This delays the anaphasic onset in somatic cells. ${ }^{24}$

Vizoso $^{25}$ evaluated the genotoxicity of extracts of Plantago lanceolata L. and Matricaria recutita L. and found that their components did not have effect on hereditary processes and the observed effects may be due to the presence of antimutagenic substances. Lopez ${ }^{26}$ evaluated the extract of Aloysia citriodora and concluded that it did not have cytotoxicity or genotoxicity effect due to the absence of active ingredients that cause any damage to single or double stranded DNA. The presence of polyphenols and monoterpenes, and their antioxidant activity would stimulate the elimination of free radicals suppressing the genotoxicity of chemical agents. ${ }^{27}$

The genotoxicity assessment in blood micronucleus (Table 2) shows a greater decrease in the average number of micronuclei in the group that received cyclophosphamide $40 \mathrm{mg} / \mathrm{kg}$ and sacha inchi oil 1000 $\mathrm{mg} / \mathrm{kg}$. Its inhibition percentage was $63.64 \%$ of the one of the group that received only cyclophosphamide $40 \mathrm{mg} / \mathrm{kg}$. The genotoxicity assessment of bone marrow shows greater decrease in the average number of micronuclei in the group that received cyclophosphamide and sacha inchi oil $100 \mathrm{mg} / \mathrm{kg}$, which showed an inhibition of $66.67 \%$ (Table 3). The presence of phytocompounds as monounsaturated ( $\omega-9)$, polyunsatured ( $\omega-3$ and $\omega-6)$ and other fatty acids (malvalic, sterculic and abietic), terpenes, steroids, $\beta$-carotene, chlorophyll, and flavonoids can explain the results. These antioxidants interrupt radical chain oxidation by donating a hydrogen atom $(\mathrm{H})$ to quench lipid peroxyl radicals and becoming another more stable radical. This new radical does not react with lipids but with other similar molecules; generating a non-radical product or quinones, which can be considered antioxidants, after undergoing further oxidation. ${ }^{28}$

This study sought to evaluate the subchronic toxicity in Carassius auratus. The growth of all the goldfish was isometric. On the other hand, there were slight variations in the condition factor of all experimental groups throughout the study. There was no significant difference in the normal evolution of the species. Therefore, sacha inchi oil does not influence on the quality of life of Carassius auratus. The values of $\mathrm{b}$ ranging from $\mathrm{b}=2.6$ and $\mathrm{b}=3.4$ show a general trend to increase thickness proportional to the size during growth. ${ }^{29}$

The values of the condition factor $(\mathrm{K})$ observed in goldfish showed a slight decrease throughout the treatment period (Figure 5). This is consistent with the findings of Visser et al. ${ }^{30}$ The highest values of $\mathrm{K}$ were during the first three weeks and would be associated with the rapid growth of goldfish when they are young, the growth rate decreased throughout weeks.

Growth in weight and length, condition factor $(\mathrm{K})$, specific percentage growth rate per day regarding the length [SGR (\%L day)] and weight [SGR (\%W day)] were evaluated weekly for 45 days (Figure 6). All experimental groups showed similar growth patterns. This homogeneity is due to factors such diet, temperature, photoperiod, growth stage and the absence of behavioral disorders and deaths in all groups. 


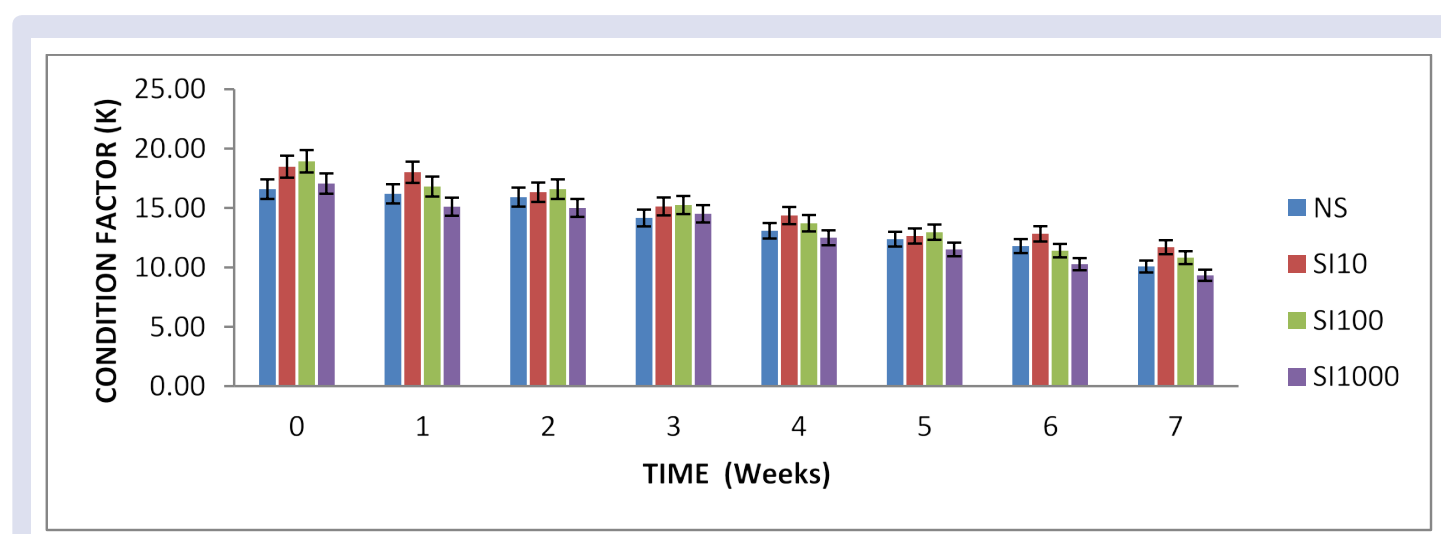

Figure 5: Condition factor $(\mathrm{k})$ of each week in the 45 days of treatment.

NS: Normal saline SI-10: sacha inchi oil $10 \mu \mathrm{g} / \mathrm{L}$, SI-100: sacha inchi oil $100 \mu \mathrm{g} / \mathrm{L}, \mathrm{SI}-1000$ : sacha inchi oil $1000 \mu \mathrm{g} / \mathrm{L}$. Where: $K=\left(W / L^{3}\right) \times 100 ;(n=6)$.

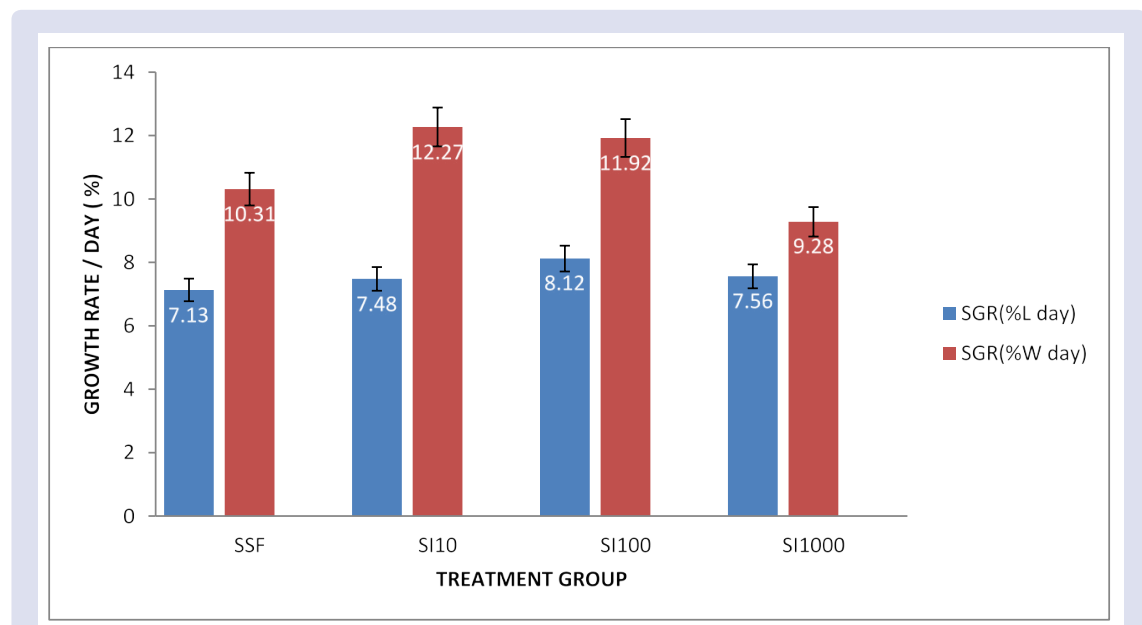

Figure 6: Specific percentage growth rate per day regarding the length [SGR (\%L DAY)] and weight [SGR (\%W DAY)] in groups in 45 days of treatment.

NS: Normal saline SI10: sacha inchi oil $10 \mu \mathrm{g} / \mathrm{L}$, SI100: sacha inchi oil $100 \mu \mathrm{g} / \mathrm{L}$, SI1000: sacha inchi oil $1000 \mu \mathrm{g} / \mathrm{L}$. Where: SGR (\%L day) $=[(\ln$ (Final length)-ln (Initial length))/treatment time $] \times 1000 ;$ SGR $(\% \mathrm{~W}$ día $)=[(\ln ($ Final weight $)-\ln ($ Initial weight $)) /$ treatment time $] \times 1000$. $(\mathrm{n}=6)$.

\section{CONCLUSIONS}

Based on the evidence described, the present study concludes that sacha inchi oil is safe. Observational studies are needed to quantify the actual consumption of sacha inchi oil among human population prior to experimental studies. The decrease in the level of micronuclei in the different experimental groups demonstrates that sacha inchi oil is not genotoxic.

\section{FUNDING}

This research received no external funding.

\section{ACKNOWLEDGMENTS}

Cesar Franco-Quino is a doctoral student studying an Epidemiological Research Doctorate at Universidad Peruana Cayetano Heredia under FONDECYT/CIENCIACTIVA scholarship EF033-235-2015 and supported by training grant D43 TW007393 awarded by Fogarti International Center of the US National Institutes of Health.

\section{CONFLICTS OF INTEREST}

The authors declare no conflicts of interest.

\section{REFERENCES}

1. Brima El. Toxic Elements in different medicinal plants and the impact on human health. Int J Environ Res Public Health. 2017;14(10):1209.

2. Sofowora A, Ogunbodede E, Onayade A. The role and place of medicinal plants in the strategies for disease prevention. Afr J Tradit Complement Altern Med. 2013;10(5):210-29.

3. Tinitana F, Rios M, Romero-Benavides JC, de la Cruz Rot M, Pardo-de-Santayana M. Medicinal plants sold at traditional markets in southern Ecuador. J Ethnobio Ethnomed. 2016;12(1):29.

4. Avila-Sosa R, Montero-Rodríguez AF, Aguilar-Alonso P, Vera-López O, LazcanoHernández M, Morales-Medina JC, et al. Antioxidant properties of amazonian fruits: a mini review of in vivo and in vitro studies. Oxid Med Cell Longev. 2019. 2019:8204129.

5. Kumar B, Smita K, Cumbal L, Debut A Synthesis of silver nanoparticles using sacha inchi (Plukenetia volubilis L.) leaf extracts. Saudi J Biol Sci. 2014;21(6):605-9.

6. Srichamnong W, Ting P, Pitchakarn P, Nuchuchua O, Temviriyanukul P. Safety assessment of Plukenetia volubilis (Inca peanut) seeds, leaves, and their products. Food Sci Nutr. 2018;6(4):962-9. 

auratus)

7. Chirinos R, Zuloeta G, Pedreschi R, Mignolet E, Larondelle Y, Campos D. Sacha inchi (Plukenetia volubilis): A seed source of polyunsaturated fatty acids, tocopherols, phytosterols, phenolic compounds and antioxidant capacity. Food Chemistry. 2013;141(3):1732-9.

8. Gorriti A, Arroyo J, Quispe F, Cisneros B, Condorhuamán M, AlmoraY, Chumpitaz V. Toxicidad oral a 60 días del aceite de Sacha inchi (Plukenetia volubilis L.) y linaza (Linum usitatissimum L.) y determinación de la dosis en roedores. Rev Peru Med Exp Salud Publica. 2010;27(3):352-60.

9. Organization for Economic Co-operation and Development (OECD). Mammalian Erythrocyte Micronucleus Test 474. París: OECD; 1997.

10. Schmid W. The micronucleus test. Mutation Res. 1975; 31:9-15.

11. Canadian Council on Animal Care. Guidelines for the use of animals in Psychology CCAC. In: Olfert ED, Cross BM, McWilliam DVM, McWilliam AA (Eds.) Ottawa: Bradda Printing Services Inc; Canada. 1997:155-62.

12. Organization for Economic Co-operation and Development (OECD). Bioaccumulation in Fish: Aqueous and Dietary Exposure 305. Paris: OECD 2011.

13. Gutiérrez H, Gutiérrez R, Herles E, Hernández, Horna P, Hoyos P, et al. Análisis comparativo de la toxicidad del extracto acuoso en cocimiento de la harina de maca (Lepidium meyenii, Walp) en tres especies de animales modelos: Artemia franciscana (Crustácea, Anostraca), pez Guppy (Poecilia Reticulata) y ratón (Mus musculus). Revista Horizonte Médico, 2007;7(2):103-8.

14. Froese R. Cube law, condition factor and weight-length relationships: history, meta-analysis and recommendations. Journal of Applied Ichthyology. 2006;22:241-53.

15. Carlander KD. Handbook of freshwater fi shery biology. University Press, The lowa State, EEUU. 1969;1(1):752.

16. Ricker WE. Computation and interpretation of biological statistics of fish popula-tions. Fisheries Bulletin Research Board of Canada. 1975;191:395.

17. Gill JA, Sumpter PJ, Donaldson EM, Dye HM, Souza L, BergT, et al. Recombinant chicken and bovine growth hormones accelerate growth in aquacultured juvenile pacific salmon Oncorhynchus kisutch. Bio/technology. 1985;(3):643-6.

18. Gollapudi B, Krishna G. Practical aspects of mutagenicity testing strategy: An industrial perspective. Mut Res [En línea]. 2000:455:21-8.
19. Hayashi M, Tice RR, MacGregor JT. In Vivo, rodent erythrocyte micronucleus assay. Mutation Res.1994;312:293-304.

20. Porter A, Singh G. Trasplancental teratogeneiss and mutagenesis in mouse fetuses treated with Cyclophosphamide. Teratogenesis, Carcinogenesis, And Mutagenesis. 1998;8:191-203.

21. Fraga JR, Domínguez M. Friman SB. González A, Somoza D, Pérez C. Evaluación genotóxica de la vacuna antileptospirósica vax-SPIRAL $®$ empleando el ensayo de micronúcleos trasplacentarios. Anuar Toxicol. 2011;1(1):35-9.

22. Cancino L, Leiva A, Garrido G, Cossío M, Prieto E. VIMANG: los efectos antigenotóxico y modulador de las enzimas glutatión peroxidasa y glutatión-Stransferasa. Rev Cubana Invest Biomed. 2001;20(1):48-53.

23. Matuo R, Oliveira RJ, Silva AF, Mantovani MS, Ribeiro LR. Anticlastogenic activity of aqueous extract of Agaricus blazei in drug-metabolizing cells (HTCs) during cell cycle. Toxic Mechan Meth. 2007;17(3):147-52.

24. Te C, Gentile JM, Baguley BC, Pearson AE. In vivo effects of chlorophyllin on antitumour agent cyclophosphamide. Int J Cancer. 1997;70(1):84-9.

25. Vizoso A, Ramos Alberto, Villaescusa Aida, Décalo M, Betancourt J. Evaluación del efecto genotóxico en extractos fluidos de Plantago lanceolata $L$. (llantén menor) y matricaria recutita L. (manzanilla). Rev Cubana Plant Med. 2000;5(2):59-63

26. Nwani CD, Lakra WS, Nagpure NS, Kumar R, Kushwaha B, Srivastava SK Toxicity of the herbicide atrazine: effects on lipid peroxidation and activities of antioxidant enzymes in the freshwater fish Channa punctatus (Bloch). Int J Environ Res Public Health. 2010;7(8):3298-12.

27. Pin-Der D, Zong-Tsi C, Shwu-Woan L, Tsuey-Pin L, Ya-Ting W, Wen-Jye Y, et al. Antiproliferative activity and apoptosis induction of eucalyptus citriodora resin and its major bioactive compound in melanoma B16F10 cells. Journal of Agricultural and Food Chemistry. American Chemical Society, 2012.

28. Singh HP, Batish DR, Setia N, Kohli RK. Herbicidal activity of volatile oils from Eucalyptus citriodora against Parthenium hysterophorus. Annals of Applied Biology. 2005;146:89-94

29. Kroon F, Streten C, Harries S. A protocol for identifying suitable biomarkers to assess fish health: A systematic review. PLoS One. 2017;12(4):e0174762.

30. Vissers M. Zock P. Katan M. Bioavailability and antioxidant effects of olive oil phenols in humans: a review. Eur J Clin Nutr. 2004;58:955-65.

\section{GRAPHICAL ABSTRACT}

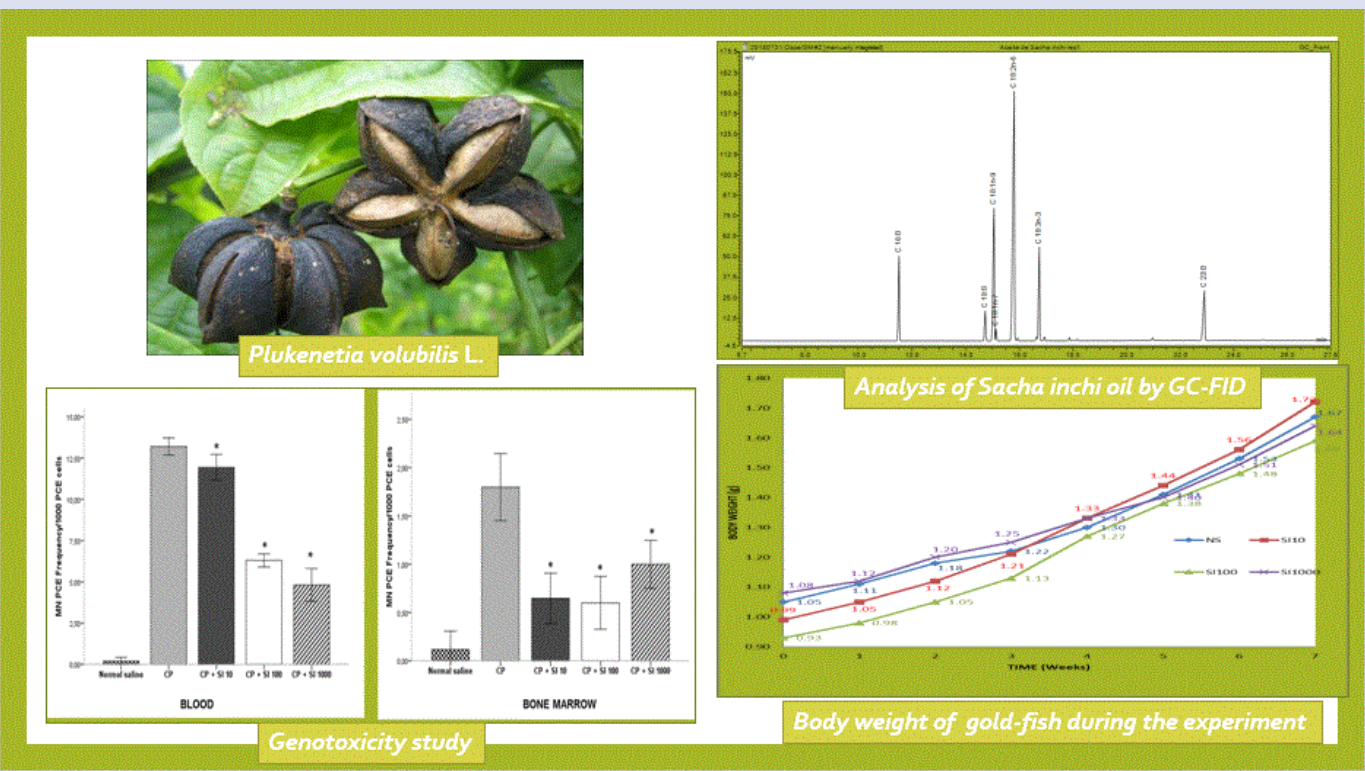

\section{ABOUT AUTHORS}

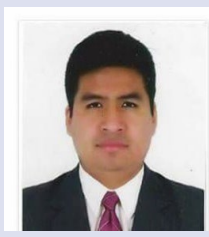

Oscar Herrera-Calderon: His expertise are natural products and the use of animals models to discover new potential drugs against different types of cancer. Active Member of the Brazilian Society of Pharmacognosy (BSP). 


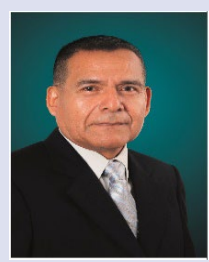

Jorge Arroyo-Acevedo: $\mathrm{He}$ is a professor and researcher in the Faculty of Medicine, Universidad Nacional Mayor de San Marcos, Lima, Peru. His expertise is Natural products with anticancer properties, and the use of animals models to discover new potential drugs against different types of cancer

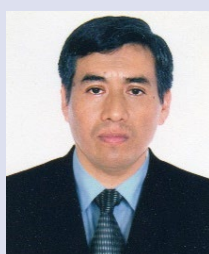

Juan Rojas-Armas: He is a professor and researcher in the Faculty of Medicine, Universidad Nacional Mayor de San Marcos, Lima, Peru. His expertise is Natural products with anticancer properties.

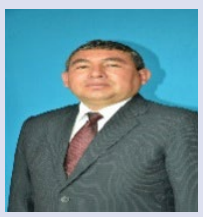

Edwin Enciso-Roca: He works at the Laboratory of toxicology, Faculty of Health Sciences, Universidad Nacional del San Cristóbal de Huamanga, Ayacucho, Peru.

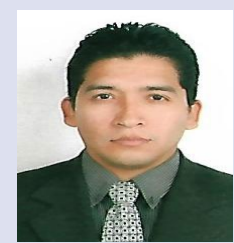

Roberto Chávez- Asmat: He is a doctor and researcher in the pharmacologic field.

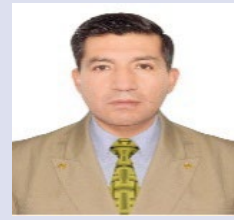

Ricardo Yuli-Posadas: He works at the Universidad Continental, Huancayo, Peru.

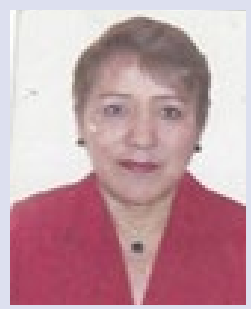

Luz Chacaltana-Ramos: She is a professor and researcher in the Faculty of Pharmacy and Biochemistry, Universidad Nacional San Luis Gonzaga, Ica.

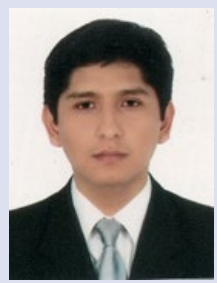

César Franco-Quino: He is studying a doctoral program in the Universidad Peruana Cayetano Heredia, Lima, Peru. 


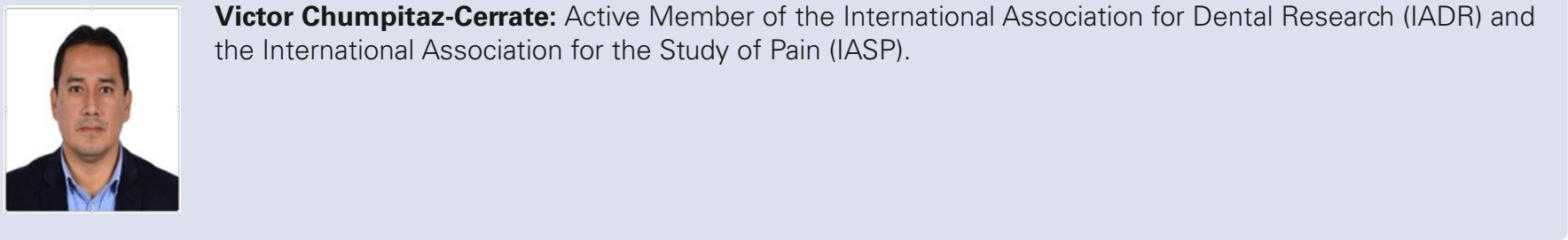

Cite this article: Herrera-Calderon $\mathrm{O}$, Arroyo-Acevedo JL, Chávez-Asmat R, Rojas-Armas JP, Enciso-Roca E, Chumpitaz-Cerrate V, et al. Effect of Sacha Inchi Oil (Plukenetia volubilis L.) on Genotoxicity in Mice (Mus musculus) and Subchronic Toxicity in Goldfish (Carassius auratus).Pharmacog J. 2019;11(6)Suppl:1549-57. 